a large hospital, more cases of hæmoptysis do not occur at one and the same time, especially when it is remembered that expectoration of blood takes place to a greater or less extent in at least 80 per cent. of cases of phthisis.

Taking these facts into consideration, then, as well as the collateral records of bæmorrhages and barometric readings, it cannot be said that observation confirms the notion that variations in atmospheric pressure have a determining influence on the outburst of pulmonary hæmorrhages. I find that this conclusion agrees with that drawn by Dr. Arthur Ransome from his investigations; $*$ and these results may be offered in response to an appeal made in a paper read before the Leeds meeting of the British Association, for careful observations "either to confirm the theory or to prove it a philosophical figment unworthy of further investigation."

Welbeck-street, $W$.

\section{DISLOCATION OF THE HIP IN A GIRL AGED EIGHT YEARS, REDUCED BY MANIPULATION, WITHOUT CHLOROFORM.}

\section{Bx H. W. COLEMAN, L.R.C.P., M.R.C.S., \&c.}

THस extreme rarity of such cases, the peculiar accident, and the mode of reduction induce me tu publish the following interesting case.

On the evening of Tuesday, April 25th, I received a message requesting me to see a daughter of Mrs. W-, residing some distance from my house, who had received a severe injury to the hip. I was unable to see the case that night, and requested my assistant, Mr. W. B. Boughton, to do so, who immediately on seeing the case diagnosed it readily.

It appears this child was being pursued down the street by two boys with iron hoops. She entered a passage dividing two blocks of houses, and having got midway was overtaken by one of the hoops passing between her legs, which threw her down with much force, and by some unaccountable circumstance she fell with one leg through a sort of trap-door into a cellar, the iron grating of which had been previously displaced.

When found she lay upon the side on which the dislocation had taken place, suffering most intensely from pain and shock, alse quite unable to stand. My assistant placed her in bed in the most comfortable position possible, and ordered hot fomentations to be applied until the case was seen by me. I may here state that the infrequency of such cases and the fact of my having only seen one similar case, and that under the care of Mr. S. Hey, during the period of four years, made me very dubious of the diagnosis.

I did not see the case until early next morning, having been called up owing to the restlessness and suffering of the child. I had her placed in the erect position by the side of the bed, and from the very characteristic features of the deformity recognised it at once as being one of dislocation of the left hip, with head of femur resting on the dorsum ilii. There was marked inversion, the knee turned inwards towards the sound side, the ball of the great toe resting on the dorsum of the right foot, and on measuring there was an inch and a half of shortening; also the head of the femur could be distinctly felt and seen in its new position.

I laid the child on the bed, flexed the thigh well on the body, rotated outwards, abducted, and suddenly extended. To my great satisfaction, and to the delight of all present, the sharp snap which is so unmistakable in these cases was audible throughout the room; and the child, whose previous sufferings were indescribable, exclaimed, "I am all right now ; the pain is gone." I put on a Liston's splint and kept her in bed for a month, and in five weeks after the accident I was somewhat surprised to find her playing in the street without a vestige of lameness.

Armley, near Leeds.

* Proceedings of Lit. and Phil. Society, Manchester, 1861.

\section{gettirror}

\section{HOSPITAL PRACTICE,}

BRITISH AND FOREIGN.

Nulla autem est alia pro certo noscendi via, nisi quamplarimas et morboram digsectionum historias, tum aliorum, tum proprias collectas habere, ef inter se comparare.-MosqdaN De Sed. et Caus. Mforb., lib. iv. Procminm,

\section{GREAT NORTHERN HOSPITAL.}

REMOVAL OF NECROSED PATELLA.

(Under the care of Mr. GAX)

THE operation for the removal of the necrosed patella has very rarely been performed. The first recorded instance seems to have occurred in the practice of M. Thirion, of Namur, in 1829. The details of that case may be found in one of the early numbers of this journal (vol. xviii. 1829). The patient recovered with a useful limb. Dr. Gross, of Philadelphia, some years ago, gouged away nearly the whole of a patella that had suffered necrosis from frost-bite; and in 1860 Dr. O. B. Knode, of Missouri, removed the whole patella for necrosis, after a fall. In both these instances a useful limb was obtained. Another case was recorded by Dr. Kelly, in the twenty-second volume of the Patholngical Transactions. It was under Mr. Wood's care at King's College Hospital, This appears to have been caused by pyæmia of the kneejoint a fortnight after a punctured wound of the forefinger by a dirty fork in a girl aged seven. The joint was freely opened, and after six weeks the patella was found loose on the surface of the wound, and was removed. Mr. Stanley does not allude to the subject in his excellent work on the Diseases of Bones.

Jessie C-, aged thirteen, when admitted on the 5 th of June, was anæmic and thin, and had been the suhject of rickets; the tibiæ, especially the right, being considerably curved, as usual, forwards. Little could be obained about the history of the case. Her mother stated that she bad always been weakly. She had had chronic sores on the nates and axillary abscesses when two years old. About January last, the right knee became painful, red, and swollen. An abscess formed over the patella, which broke spontaneously; the opening enlarged, and the surface of the patella gradually extruded.

On admission, the patella was found necrosed, with matter oozing from the contiguous soft parts. The joint was extended, and extremely painful both on pressure and on the slightest attempt at flexion. When moved, a sense of extensive creaking or crackling was perceptible within the joint. The child was in a very low condition, and it was deemed desirable to do something surgically without delay in order to save life.

Mr. Gay determined on removing the patella. This was done on June 14th. On the removal of the bone, the joint appeared to be full of red granulation-tissue, upon which the under surface of the patella rested, and to which it was somewhat adherent. It completely obstructed any view of the in terior.

The limb was placed on a back splint and slung. Not a single bad symptom followed. The wound healed, and by the middle of July the girl was up and about. There was considerable movement of the joint without pain, and al creaking sound had ceased. By the latter end of the month she began to walk about with the assistance of a stick. Sho will probably recover the use of her limb to nearly the same extent as those in whom fracture of the patella has issued in union with extensive separation of the fragments.

There was no history in this case from which the immediate cause of the necrosis could be inferred; no blow or other local or special constitutional injury other than the struma referred to. The bone perished, and the abseess formed in order to effect its release. The bone was small and the cancellous cells large, but without any signs of their having been subjected to an attack of osteo-myelitis. It is probable that the necrosis in this case was due to direct injury and low vital power.

The bone was bare excepting at its artionlar surface, from 